\title{
Histopathological, immunohistochemical, and parasitological studies on pathogenesis of Coenurus cerebralis in sheep
}

\author{
Yilmaz Rahsan ${ }^{1}$, Yumusak Nihat ${ }^{1}$, Yilmaz Bestami $^{2}$, Ayan Adnan ${ }^{3}$, Aysul Nuran ${ }^{4}$ \\ ${ }^{1}$ Department of Pathology, ${ }^{2}$ Department of Anatomy, \\ Faculty of Veterinary Medicine, Harran University, 63200, Sanliurfa, Turkey \\ ${ }^{3}$ Department of Genetics, Faculty of Veterinary Medicine, Yuzuncu Y1l University, 65080, Van, Turkey \\ ${ }^{4}$ Department of Parasitology, Faculty of Veterinary Medicine, Adnan Menderes University, 09016, Aydin, Turkey \\ rmilliogullari@hotmail.com
}

Received: December 19, 2017 Accepted: March 9, 2018

\begin{abstract}
Introduction: This study consisted in histopathological and immunohistochemical examinations of the central nervous system of 15 sheep suspected of infection with Coenurus cerebralis. The sheep displayed compulsive circling and were submitted for necropsy in 2012-2016. Material and Methods: Species identification was made on the basis of the PCR analysis and parasitological examination of the cysts. Results: Coenurus cerebralis cysts were detected only in the cerebral tissue of 13 sheep and in the cerebral and cerebellar tissues of 2 animals. Out of the 33 parasite cysts, most $(21.21 \%)$ were located in the right and left frontal lobes of the cerebrum. The largest cyst measured $6 \times 5 \mathrm{~cm}$ and the smallest cyst was $2 \times 2 \mathrm{~cm}$ in size. The highest and lowest numbers of scolices were 55 and 21, and the number of rostellar hooks ranged between 22 and 30. Histopathological examination revealed the presence of typical parasitic granulomatous inflammatory foci. Immunohistochemical staining showed that most common in the periphery of the parasite cysts were, in descending order by cell number, GFAP, CD163, CD3, and CD79 $\alpha$-positive cells. Conclusion: The study confirms the role of cellular defence mechanisms in the pathogenesis of Coenurus cerebralis infection in sheep.
\end{abstract}

Keywords: sheep, Coenurus cerebralis, histopathology, PCR, immunohistochemistry.

\section{Introduction}

Coenurosis is a major zoonotic parasitic infection, which is caused by Coenurus cerebralis, the larval stage of the tapeworm Taenia multiceps, and is generally observed in small ruminants $(17,18,24-26)$. The larvae invade the central nervous system of the intermediate hosts, which include sheep, goats, cattle, buffaloes, yaks, pigs, deer, horses, camels, and humans (10, 17, 20, 21, $25,26)$. The intermediate hosts become infected by ingesting feed or food contaminated with Taenia multiceps eggs (21). Coenurus cerebralis inhabits the small intestine of the definitive hosts, which include carnivores such as dogs, coyotes, and foxes (17). Coenurosis is observed in either acute or chronic form. The acute form generally occurs in 6- to 8-week-old lambs. Four to five days after the onset of clinical signs, including fever, fatigue, head pressing, and convulsions, death occurs. The chronic form is most common in animals aged 6-18 months. The migration of the parasite to the central nervous system and the development of the parasitic lesions take several months (19). The larvae, which invade the central nervous system and primarily the cerebrum in the intermediate host, develop into transparent cysts, which range between 0.3 and $9.5 \mathrm{~cm}$ in diameter and contain a translucent fluid and hundreds of scolices invaginating from the inner wall of the cysts (8). The symptoms associated with coenurosis vary with the location and size of the cysts as well as with the pressure the cysts exert on the cerebrum $(12,20)$. Coenurus cerebralis firstly causes purulent meningoencephalitis, and once the cyst matures, it leads to central nervous system degeneration which may result in death (7). The most characteristic clinical signs of the disease are observed within the first 2-8 months after the ingestion of the parasite eggs (20) and involve locomotor symptoms (2). As a result of the pressure exerted by the Coenurus cerebralis cysts on the cerebrum but 
depending on the location of the cysts in the central nervous system, the animal hangs its head to the side where the cyst is located, walks in circles, and knocks against surrounding objects as it is unable to hold its head upright. Furthermore, various other clinical symptoms, including ataxia, incoordination, paresis, torticollis, teeth grinding, blindness, coma, cerebral atrophy, and deformation and thinning of the cranial bones may also be observed $(3,11,14)$. Clinical symptoms may be suggestive of the disease, yet definitive diagnosis is made on the basis of the detection of parasite cysts in the cerebrum (20). While 80\%-90\% of the cysts are localised in the cerebral hemispheres, $5 \%-10 \%$ are located in the cerebellum (19). This study was aimed at demonstrating the morphology and histopathology of coenurosis and characterising the inflammatory response of the host to the parasite.

\section{Material and Methods}

The cerebral and cerebellar tissues of 15 sheep and lambs of different breeds and ages were submitted to the Pathology Department of Harran University, Faculty of Veterinary Medicine for necropsy. These tissues, necropsied between 2012 and 2016 in the Sanliurfa region of Turkey, constituted the material of the study.

Macroscopic examination. During macroscopic examination parasite cysts were found in the cerebral and cerebellar tissues. The size of the cerebral and cerebellar cysts was measured.

Parasitological examination. All the cysts contained protoscolices. The protoscolices were first fixed in $70 \%$ ethanol, then stored at $-20^{\circ} \mathrm{C}$. A PureLinkTM Genomic DNA Kit (Invitrogen, USA) was used for DNA extraction. The $446 \mathrm{bp}$-cytochrome c oxidase subunit I (CO1) gene region of Coenurus cerebralis was amplified using the JB3 (5'-TTTTTTGGGCA TCCTGAGGTTTAT-3') and JB4.5 (5'-TAAAG AAAGAACATAATGAAAATG-3') primers (6) according to the protocol described by Rostami et al. (16) for this parasite. Accordingly, $1.75 \mathrm{mM}$ of $\mathrm{MgCl}_{2}, 125 \mathrm{mM}$ of each dNTP, 10 pmol of each primer, $1 \mathrm{U}$ of Taq polymerase, and $2 \mu \mathrm{L}(16-50 \mathrm{ng} / \mathrm{mL})$ of DNA were mixed for each $25 \mu \mathrm{L}$ of PCR reaction. PCR amplification was performed with an initial denaturation step of $5 \mathrm{~min}$ at $94^{\circ} \mathrm{C}$, followed by 35 cycles of $3 \mathrm{~s}$ at $94^{\circ} \mathrm{C}, 4 \mathrm{~s}$ at $50^{\circ} \mathrm{C}, 35 \mathrm{~s}$ at $72^{\circ} \mathrm{C}$, and a final extension step of $10 \mathrm{~min}$ at $72^{\circ} \mathrm{C}$. Next, a $1.5 \%$ agarose gel was prepared and the PCR products were run on the gel at 90 volts for $1 \mathrm{~h}$. Subsequently, imaging was performed using a UV transilluminator (EC3 ChemiHR 410 Imaging System, UVP, USA).

Histopathological examination. The brain and cerebellum tissues were fixed in $10 \%$ formalin. The samples were processed routinely and stained with haematoxylin and eosin.

Immunohistochemical examination. Inflammatory lesions caused by the parasite were stained immunohistochemically using the streptavidin-biotinperoxidase method. Stainings performed for the measurement of the inflammatory response demonstrated the presence of anti-CD3 antibody T cells, CD79+ B cells, and CD163+ macrophages around the cyst. An ovine mediastinal lymph node was used as the positive control in the immunohistochemical staining and an antibody diluent not containing primary antibodies was used as the negative control. Glial fibrillary acidic protein (GFAP) antibodies produced by astrocytes, which are activated in neurodegenerative disorders, were also used.

For immunohistochemistry, monoclonal rabbit anti-human CD3 diluted 1:150, (Invitrogen, USA), monoclonal mouse anti-human $\mathrm{CD} 79 \alpha$ diluted 1:50 (DAKO, Germany), monoclonal mouse anti-human CD163 diluted 1:50 (Invitrogen, USA), and polyclonal mouse anti-human GFAP diluted 1:300 (DAKO, Germany) comprised the primary antibodies, and polyclonal biotinylated goat anti-polyvalent was the secondary antibody (TP-125-BN, Lab Vision, USA). The antibodies differed for the immunohistochemical staining procedure. These differences are presented in Table 1. All immunohistochemically stained sections were examined under a light microscope. In view of the distribution and intensity of the immunohistochemical staining, five regions were randomly selected in each section using a $40 \times$ objective, and the positively stained cells were counted in these regions.

Statistical analysis. The arithmetic means of the numbers of positively stained cells were used for statistical analyses, counted in five different regions in the sections prepared from each sample. The normality of the data was assessed using the Shapiro-Wilk test. Differences between the cells with respect to the numbers of cells stained positively for different antibodies were tested for significance using one-way analysis of variance for repeated measures.

Table 1. Differences in immunohistochemical staining protocol

\begin{tabular}{|c|c|c|c|c|}
\hline & CD3 & CD79 $\alpha$ & CD163 & GFAP \\
\hline Antigen retrieval & $\begin{array}{l}20 \mathrm{~min}, 120^{\circ} \mathrm{C}, 1 \mathrm{~atm}, \\
\text { autoclave, citrate buffer }\end{array}$ & $\begin{array}{l}20 \min , 120^{\circ} \mathrm{C}, 1 \\
\text { atm, autoclave, } \\
\text { citrate buffer }\end{array}$ & $\begin{array}{l}10 \text { min, } 800 \text { watt, } \\
\text { microwave, citrate } \\
\text { buffer }\end{array}$ & $\begin{array}{l}15 \text { min, room } \\
\text { temperature, microwave, } \\
\text { proteinase } \mathrm{K}\end{array}$ \\
\hline $\mathrm{H}_{2} \mathrm{O}_{2}$ & $30 \mathrm{~min}$ & $25 \mathrm{~min}$ & $30 \mathrm{~min}$ & $15 \mathrm{~min}$ \\
\hline $\begin{array}{l}\text { Primer antibody application, time } \\
\text { and temperature }\end{array}$ & $\begin{array}{l}1 \mathrm{~h}, \\
\text { room temperature }\end{array}$ & $\begin{array}{l}1 \mathrm{~h}, \\
\text { room temperature }\end{array}$ & $\begin{array}{l}30 \mathrm{~min}, \\
\text { room temperature }\end{array}$ & $\begin{array}{l}1 \mathrm{~h} \\
37^{\circ} \mathrm{C}\end{array}$ \\
\hline $\begin{array}{l}\text { 3,3'-diaminobenzidine } \\
\text { tetrahydrochloride (DAB) }\end{array}$ & $10 \mathrm{~min}$ & $10 \mathrm{~min}$ & $7 \mathrm{~min}$ & $3 \mathrm{~min}$ \\
\hline
\end{tabular}


Pairwise comparison for antibodies was made using the Bonferroni test. Pearson's correlation test was applied to determine whether a correlation existed between the numbers of cells stained positively for different antibodies. For statistical analyses, the Statistical Software Package for Social Sciences, version 11.0 (SPSS 11.0, IBM-SPSS, USA) was used.

\section{Results}

Macroscopic results. Parasite cysts were localised only in the cerebral tissue in 13 animals and in the cerebral and cerebellar tissues in 2 animals. The localisations of the cysts in the cerebrum and cerebellum were superficial and the cysts were of varying size, had a fluctuant consistency, and contained many white coloured scolices (Fig. 1A). the number and location of the parasite cysts and the number of scolices are given in Table 2. Overall, 33 parasite cysts were detected in the cerebra and cerebella. Seven $(21.21 \%)$ cysts were located in the right and left frontal cerebral lobes, six $(18.18 \%)$ in the right and left parietal lobes, two (6.06\%) in the right and left temporal lobes, and one $(3.03 \%)$ in an occipital lobe. Two $(6.06 \%)$ cysts were detected in the cerebellar tissue. The largest cyst measured $6 \times 5 \mathrm{~cm}$ and the smallest one was $2 \times 2 \mathrm{~cm}$ in size.

Parasitological results. The highest number of scolices was 55 and the lowest was 21. The number of rostellar hooks ranged between 22 and 30. Fresh unstained samples of the internal fluid of the cyst revealed the rose thorn protoscolices typical for Taenia multiceps. The scolices had four suckers and one rostellum armed with a double crown of around 25-30 hooks with hooklets. The hooks and hooklets were 175 and $119 \mu \mathrm{m}$ in length respectively, and the suckers were $325 \mu \mathrm{m}$ each in diameter. Histologically, the cyst was composed of a single capsule composed of a thick wall with a dense outer eosinophilic layer and an areolar, disorganising inner layer. The wall of the cyst was continuous with multiple invaginated protoscolices. The protoscolices were characterised by a prominent scolex with refractile hooklets and suckers. RT-PCR and PCR results demonstrated that the samples tested in this study were all positive for T. multiceps (Fig. 2).
Histopathological findings. The histopathological examination of the sections prepared from the cerebral and cerebellar tissues demonstrated hyperaemia and mononuclear cell infiltration in the regions in the proximity of the cysts. Furthermore, foreign body giant cells, moderate mononuclear cell infiltration, and calcification in some of the sections were observed in the periphery of the cyst wall (Fig. 1B). Perivascular cuffing in the white matter, mild microgliosis and astrocytosis, demyelination, degeneration of a few neurons, necrosis, non-purulent meningitis (Fig. 1C), and hyperaemia of the meningeal blood vessels were observed in the area surrounding the cysts.

$C_{3}, C D 79 \alpha$, and CD163 staining results. The $\mathrm{CD}_{3}$ (Figs $3 \mathrm{~A}$ and $\mathrm{B}$ ) and CD79 $\alpha$ (Figs $3 \mathrm{C}$ and D) positively stained cells displayed dark brown stained cell membranes and the CD163 positively stained cells displayed dark brown stained cytoplasm. Positive stained cells were macrophages and giant cells located in the perivascular cuffing areas and around the cyst (Figs 3 E, F).

GFAP staining results. Positively stained cells displayed a diffuse distribution in the cerebral and cerebellar parenchyma and were present in neurons and astrocytes (Fig. 3G). Staining was observed as a dark brown colour of the cytoplasm and cytoplasmic extensions (Fig. $3 \mathrm{H}$ ).

Microscopic examination of the immunohistochemically stained sections showed that, quantitatively, the rank order of staining intensity was as follows: GFAP $>$ CD163 $>$ CD3 $>$ CD79 $\alpha$.

Statistical results. The differences between the number of positive cells in the sections stained with different antibodies were found to be statistically significant $(\mathrm{P}<0.001)$. The difference detected between the antibodies for the number of positive cells on the basis of multiple comparison was also found to be statistically significant (Table $3, \mathrm{P}<0.001$ ).

The correlation between the numbers of positive cells obtained with different antibodies is shown in Table 4. Accordingly, the correlation between the groups was ascertained to be statistically insignificant $(\mathrm{P}>0.05)$.

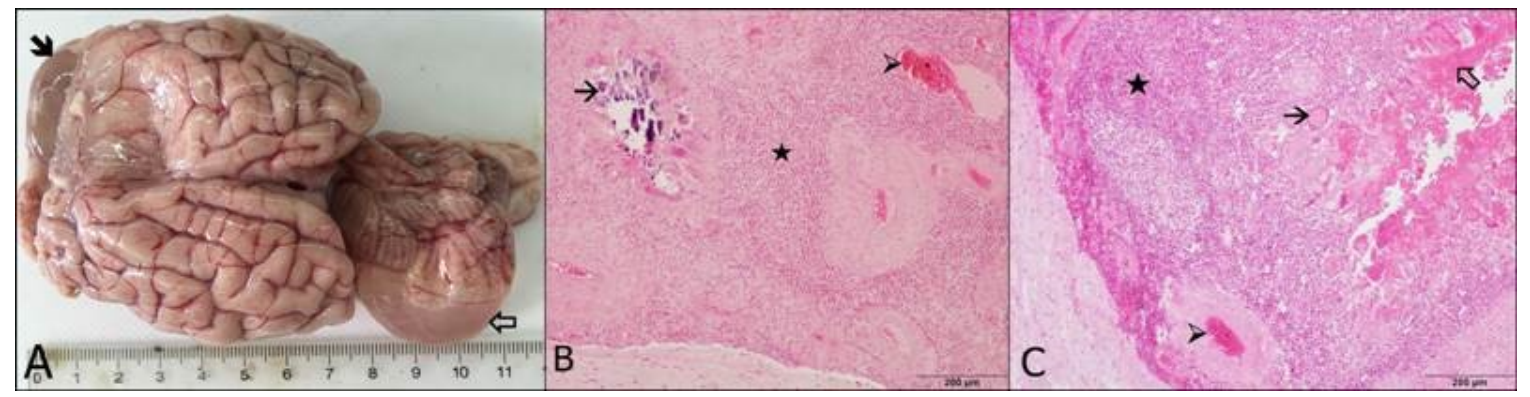

Fig. 1. A - macroscopic appearance of cysts in the brain and cerebellum. Coenurus cysts in the right frontal lobe (black arrow) and in the left cerebellum (white arrow). B - microscopical appearance of the inflamed area around the cyst in the brain. Calcification (thin arrow), mononuclear cell infiltration (white arrow), hyperaemia (arrowhead), H\&E, 100×. C - giant cell (thin arrow), mononuclear cell infiltration (asterisk), necrosis (white arrow), hyperaemia (arrowhead), H\&E, 100× 


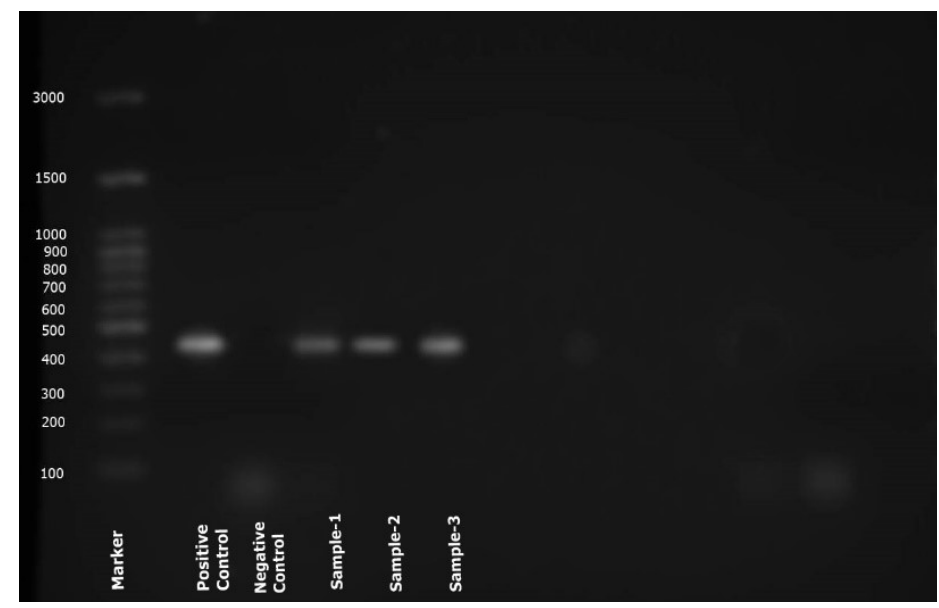

Fig. 2. 2\% gel electrophoresis image of some positive samples in the PCR process (446 bp)

Table 2. Cyst location and scolex numbers

\begin{tabular}{|c|c|c|c|c|c|}
\hline No & Sex & Age & Cyst location & Size of cyst & Scolex number \\
\hline \multirow{2}{*}{1} & \multirow{2}{*}{ Male } & \multirow{2}{*}{1 year } & Left parietal lobe & $6 \times 5 \mathrm{~cm}$ & 53 \\
\hline & & & Right parietal lobe & $5 \times 4 \mathrm{~cm}$ & 47 \\
\hline \multirow{2}{*}{2} & \multirow{2}{*}{ Female } & \multirow{2}{*}{6 months } & Left parietal lobe & $4 \times 3 \mathrm{~cm}$ & 38 \\
\hline & & & Right parietal lobe & $4 \times 3 \mathrm{~cm}$ & 36 \\
\hline \multirow{3}{*}{3} & \multirow{3}{*}{ Male } & \multirow{3}{*}{9 months } & Left frontal lobe & $5 \times 4.5 \mathrm{~cm}$ & 49 \\
\hline & & & Right frontal lobe & $3 \times 2 \mathrm{~cm}$ & 26 \\
\hline & & & Right parietal lobe & $3 \times 2 \mathrm{~cm}$ & 29 \\
\hline \multirow{2}{*}{4} & \multirow{2}{*}{ Female } & \multirow{2}{*}{2 years } & Left parietal lobe & $6 \times 5 \mathrm{~cm}$ & 55 \\
\hline & & & Right parietal lobe & $5 \times 4 \mathrm{~cm}$ & 45 \\
\hline \multirow{4}{*}{5} & \multirow{4}{*}{ Male } & \multirow{4}{*}{6 months } & Right parietal lobe & $3 \times 2.5 \mathrm{~cm}$ & 32 \\
\hline & & & Right temporal lobe & $3 \times 2 \mathrm{~cm}$ & 24 \\
\hline & & & Left frontal lobe & $3 \times 2 \mathrm{~cm}$ & 25 \\
\hline & & & Left parietal lobe & $3 \times 2 \mathrm{~cm}$ & 28 \\
\hline \multirow{2}{*}{6} & \multirow{2}{*}{ Male } & \multirow{2}{*}{1 year } & Left frontal lobe & $5 \times 4.5 \mathrm{~cm}$ & 38 \\
\hline & & & Right frontal lobe & $5 \times 5 \mathrm{~cm}$ & 48 \\
\hline \multirow{2}{*}{7} & \multirow{2}{*}{ Female } & \multirow{2}{*}{1 year } & Left frontal lobe & $6 \times 5 \mathrm{~cm}$ & 53 \\
\hline & & & Right frontal lobe & $4 \times 5 \mathrm{~cm}$ & 50 \\
\hline \multirow{2}{*}{8} & \multirow{2}{*}{ Female } & \multirow{2}{*}{4 years } & Left frontal lobe & $4 \times 3$ & 32 \\
\hline & & & Right frontal lobe & $4 \times 3$ & 30 \\
\hline \multirow{4}{*}{9} & \multirow{4}{*}{ Male } & \multirow{4}{*}{6 months } & Left frontal lobe & $3 \times 3$ & 28 \\
\hline & & & Right frontal lobe & $3 \times 3$ & 26 \\
\hline & & & Left parietal lobe & $2 \times 2.5$ & 21 \\
\hline & & & Right parietal lobe & $2 \times 2.5$ & 24 \\
\hline 10 & Male & 8 months & Left temporal lobe & $4 \times 3$ & 36 \\
\hline \multirow{2}{*}{11} & \multirow{2}{*}{ Male } & 6 months & Left temporal lobe & $3 \times 3$ & 33 \\
\hline & & o illonitus & Right temporal lobe & $3 \times 2$ & 21 \\
\hline 12 & Female & 25 vears & Left occipital lobe & $3 \times 3$ & 33 \\
\hline 12 & Itintaic & $2.0 \mathrm{y}$ als & Right occipital lobe & $3 \times 2$ & 25 \\
\hline 13 & Male & 7 months & Right frontal lobe & $3 \times 3.5 \mathrm{~cm}$ & 38 \\
\hline 13 & 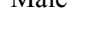 & / $11100111 \mathrm{~s}$ & Cerebellum & $2 \times 2 \mathrm{~cm}$ & 30 \\
\hline 14 & Male & 7 months & Cerebellum & $3 \times 2 \mathrm{~cm}$ & 30 \\
\hline 15 & Female & 1 vear & Left frontal lobe & $5 \times 6 \mathrm{~cm}$ & 47 \\
\hline & & 1 year & Right frontal lobe & $4 \times 3 \mathrm{~cm}$ & 35 \\
\hline
\end{tabular}




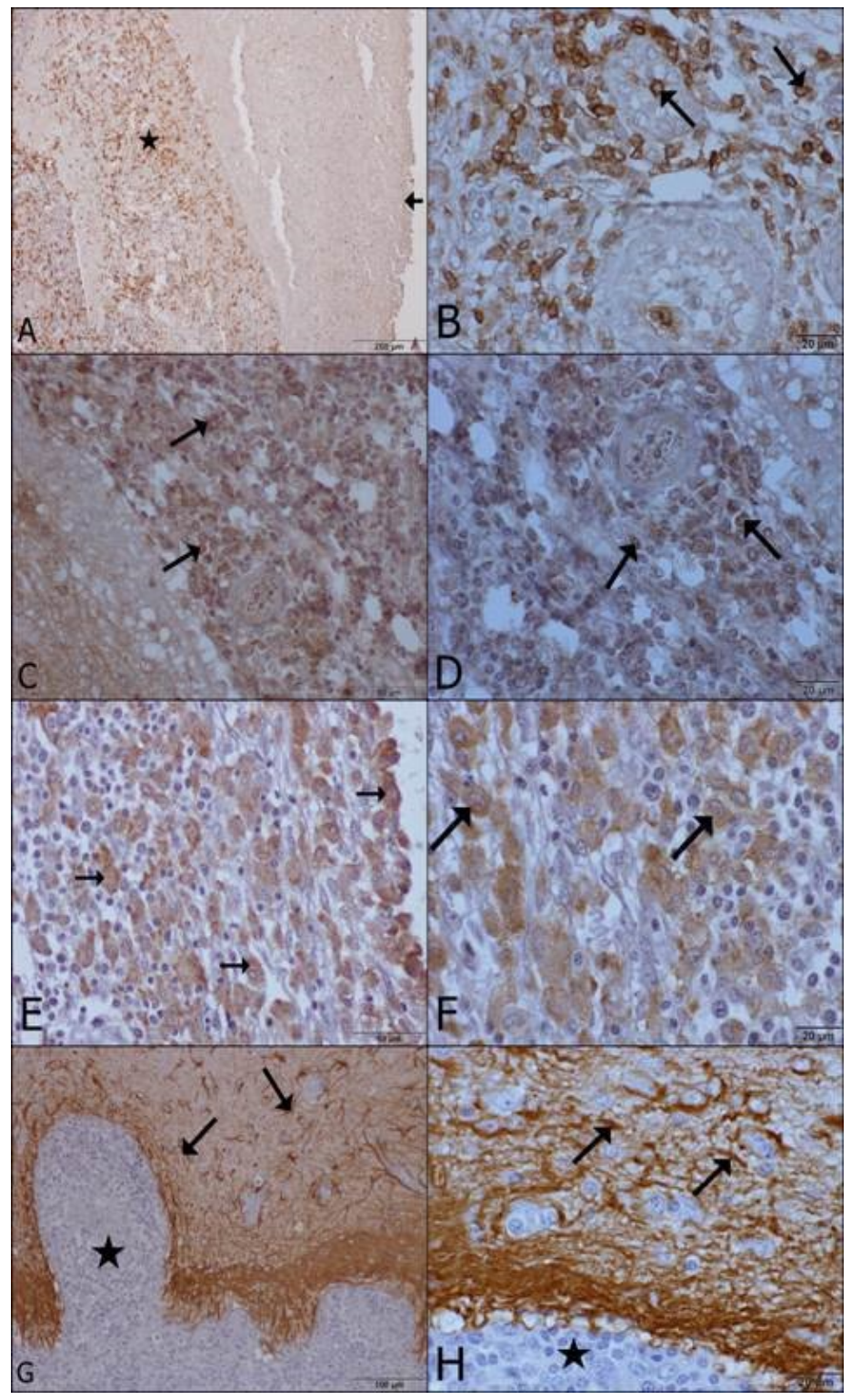

Fig. 3. Microscopical appearance of positive staining cells CD3, CD79 $\alpha$, CD163, and GFAP. A - CD3 positive cells (asterisk), necrosis (black arrow), IHC staining, $100 \times$. B - CD 3 positive cells (black arrow), IHC staining, $600 \times . C-C D 79 \alpha$ positive cells (black arrow), IHC staining, $\times 400$. D - CD79 $\alpha$ positive cells (black arrow), IHC staining, 600 $\times$. E - CD163 positive cells (black arrow), IHC staining, 400 $\times$. F - CD163 positive cells (black arrow), IHC staining, 600×. G - GFAP positive cells (black arrow), mononuclear cell infiltration (asterisk) IHC staining, 200×. $\mathrm{H}$ - GFAP positive cells (black arrow), IHC staining, 600×

Table 3. Difference between positive stained cell numbers using different antibodies

\begin{tabular}{llll}
\hline Antibody & \multicolumn{1}{c}{$\mathrm{X} \pm \mathrm{SE}$} & Min & Max \\
\hline CD3 & $31.68 \pm 2.362^{\mathbf{a}}$ & 22.6 & 51.2 \\
\hline CD79 & $18.627 \pm 0.705^{\mathbf{b}}$ & 13.4 & 24.2 \\
\hline CD163 & $57.147 \pm 3.68^{\mathbf{c}}$ & 30.4 & 80.0 \\
\hline GFAP & $85.347 \pm 0.609^{\mathbf{d}}$ & 80.0 & 89.0 \\
\hline $\mathrm{P}<0.001$ & & &
\end{tabular}

Different letters indicate that the difference between the different lines is statistically significant
Table 4. Correlation between positive stained cell numbers using different antibodies

\begin{tabular}{lccc}
\hline Antibody & CD3 & CD79 & CD163 \\
\hline CD3 & & & \\
\hline CD79 & 0.351 & & \\
\hline CD163 & -0.218 & -0.059 & \\
\hline GFAP & 0.0214 & -0.024 & 0.14 \\
\hline
\end{tabular}




\section{Discussion}

Coenurosis, which is generally observed in small ruminants, remains a major and common parasitic infection (19). Coenurosis is a zoonotic parasitic disease of sheep and goats, which is caused by Coenurus cerebralis, the larval stage of Taenia multiceps. Coenurus cerebralis, which can be fatal for sheep and goats, inhabits the small intestine of its definitive hosts, which include carnivores such as dogs, coyotes, and foxes (17).

Some researchers have reported that the parasite cysts are mostly localised to the parieto-occipital region (10). The present study demonstrated that the cysts were located in the frontal and parietal lobes of the cerebral tissue. This finding suggests that the parasite cysts may develop in any region of the central nervous system. The size of Coenurus cerebralis cysts has been reported to range between 0.5 and $4.2 \mathrm{~cm}$ by Biyıkoğlu (5), 1.7-6.3 cm by Akkaya et al. (3), and 0.8-6.5 cm by Achenef et al. (1). In the present study, while the largest cyst measured $6 \times 5 \mathrm{~cm}$, the smallest cyst was $2 \times 2 \mathrm{~cm}$ in size. In previous research, the prevalence of Coenurus cerebralis was reported as $36.8 \%$ in sheep in Turkey (23), $15.5 \%$ in the Kars region of Turkey (9), $45.6 \%$ (sheep) and $43.3 \%$ (goats) in Tanzania (13), 18.65\% in Iran (22), and 14.8\% in Mozambique (4). In the present study, the highest and lowest numbers of scolices detected in the cysts were 55 and 21, and the number of rostellar hooks in the scolices ranged between 22 and 30. RT-PCR and PCR results confirmed that the parasite was the larval stage of Taenia multiceps, and the parasitological results obtained were found to be in agreement with those reported in former research (1).

Several literature reports are available on the histopathological investigation of parasite cysts localised to the cerebral and cerebellar tissues and the inflammatory lesions in the periphery of these cysts. In agreement with previous research $(11,14,23)$, in the present study histopathological examination demonstrated a marked hyperaemia around the cyst, foreign body giant cells, moderate mononuclear cell infiltration, and in some sections calcification in the periphery of the cysts, as well as perivascular cuffing, mild microgliosis and astrocytosis in the white matter near the cysts, and also demyelination, degeneration of a few neurons, necrosis, non-purulent meningitis, and hyperaemia of the meningeal blood vessels.

To the authors' knowledge, there is no previous microscopic study on the inflammatory cells surrounding coenurosis lesions in the central nervous system. In order to reach the goal of demonstrating the distribution of inflammatory cells in the parasitic granulomatous inflammation due to Coenurus cerebralis, immunohistochemistry was employed on CD3 for T cells, CD79 for B cells, CD163 for macrophage cells, and GFAP for neurodegenerative cells. This study was designed to provide information on this particular topic, on the CD3-, CD79 $\alpha$-, and CD163- positive cells found in the periphery of the lesions and in the tissue parenchyma, and on the presence of the more proliferatively expressed GFAP as demonstrated with immunohistochemical staining methods (15). Granulomatous inflammation is best defined as a special variety of chronic inflammation in which cells of the mononuclear phagocyte system are predominant and take the form of macrophages, epithelioid cells, and multinucleated giant cells. In addition there is usually an admixture of other cells, especially lymphocytes, plasma cells, and fibroblasts (27). In this study, immunohistochemical examination revealed that macrophages (CD163+) were the dominating cell population in the inflammatory reaction observed in the lesions. Furthermore, it was determined that the expression of GFAP had increased, which is produced by astrocytes that are activated in the event of neurodegenerative disorders. The difference observed between the immunohistochemically stained cells was found to be statistically significant $(\mathrm{P}<0.001)$, confirming these results. In particular, the quantitative differences determined between the staining intensity of the cells involved in the cellular immune response, such as macrophages (CD163), T lymphocytes (CD3), and B lymphocytes $(C D 79 \alpha)$ suggest that in parasitic infections like coenurosis which cause chronic granulomatous lesions the predominating cell type is the macrophage.

It is hoped that the results of the present study will light the way for future pathological and parasitological research to be conducted on this subject.

Conflict of Interests Statement: The authors declare that there is no conflict of interests regarding the publication of this article.

Financial Disclosure Statement: This study was supported by the Scientific Research Council of Harran University (Grant No. 15062).

Animal Rights Statement: None required.

\section{References}

1. Achenef A., Markos T., Feseha G., Hibret A., Teembely S.: Coenurus cerebralis infection in Ethiopian Highland Sheep: incidence and observations on pathogenesis and clinical signs. Trop Anim Health Pro 1999, 31, 15-24.

2. Akbari M., Moazeni M., Oryan A., Sharifiyazdi H., Amrabadi O.: Experimental cerebral and non-cerebral coenurosis in goats: a comparative study on the morphological and molecular characteristics of the parasite. Vet Parasitol 2015, 211, 201-207.

3. Akkaya H., Vuruşaner C.: Coenuriasis cerebralis in sheep and calves slaughtered in Istanbul (in Turkish). (İstanbul'da kesilen koyunlarda ve danalarda Coenurus cerebralis). Acta Parasitol Turc (Turkiye Parazitol Derg) 1998, 22, 320-324.

4. Afonso S.M.S., Mukaratirwa S., Hajovska K., Capece B.P.S., Cristòfol C., Arboix, M., Neves L.: Prevalence and morphological characteristics of Taenia multiceps cysts (Coenurus cerebralis) from abattoir-slaughtered and experimentally infected goats. J Neuroparasitol 2011, 2, 1-5. 
5. Biyıkoğlu G., Effects of Praziquantel and Albendazole on Coenurus cerebralis in experimentally infected lambs (Deneysel olarak enfekte kuzularda Coenurus cerebralis'e praziquantel ve albendozol'un etkisi) (doctoral thesis) (in Turkish). Ankara University Graduate School of Health Sciences (A. Ü. Sağlık Bilimleri Enstitüsü), 1995, Ankara.

6. Bowles J., Blair D., McManus D.P.: Genetic variants within the genus Echinococcus identified by mitochondrial DNA sequencing. Mol. Biochem. Parasitol 1992, 54, 165-173.

7. Christodoulopoulos G.: Two rare clinical manifestations of coenurosis in sheep. Vet Parasitol 2007, 143, 368-370.

8. Eckert J., Friedhoff K.T., Zahner H., Deplazes P.: Textbook of Parasitology for Veterinary Medicine (in German) (Lehrbuch der Parasitologie für die Tiermedizin). Enke Verlag, Stuttgart, 2008.

9. Gicık Y., Kara M., Arslan M.O.: Prevalence of Coenurus cerebralis in sheep in Kars province, Turkey. Bull Vet Inst Pulawy 2007, 51, 379-382.

10. Gogoi D., Lahon D.K., Bhattacharya M., Lekharu J.C.: Histopathological studies on coenurosis in goat. Indian J Anim Sci 1991, 61, 283-285.

11. Gökpınar S., Yıldız K.: Prevelance of coenurosis in clinically healthy sheep (Klinik bakımdan sağlıklı görünümlü koyunlarda Coenurosisin yayğınlığı) (in Turkish) J Faculty Vet Med, Kafkas University (Kafkas Univ Vet Fak Derg) 2012, 18, 187-191.

12. Gul Y., Issi M., Ozer S.: Clinical and pathological observations of flock of sheep showing epileptoid spasm related to oestrosis and coenurosis. Firat University Vet J Health Sci (FÜ Sağ Bil Vet Derg) 2007, 21, 173-177.

13. Miran M., Nzalawahe B., Kassuku J., Swai E.S.: Prevalence of coenurosis in sheep and goats at three slaughter slabs in Ngorongoro District, Tanzania. Trop Anim Health Prod 2015, 47, 1591-1597.

14. Ozmen O., Sahinduran S., Haligur M., Sezer K.: Clinicopathologic observations on Coenurus cerebralis in naturally infected sheep. Schweiz Arch Tierheilk 2006, 147, 129-134.

15. Papparella S.: Histology in diagnosis of parasitic diseases. Parassitologia 2004, 46, 157-158.
16. Rostami S., Salavati R., Beech R.N., Sharbatkhori M., Babaei Z., Saedi S., Harandi M.F.: Cytochrome c oxidase subunit 1 and 12S ribosomal RNA characterization of Coenurus cerebralis from sheep in Iran. Vet Parasitol 2013, 197, 141-151.

17. Scala A., Varcasia A.: Updates on morphobiology, epidemiology, and molecular characterization of coenurosis in sheep. Parassitologia 2006, 48, 61-63.

18. Scala A., Pipia A.P., Dore F., Sanna G., Tamponi C., Marrosu R., Bandino E., Carmona C., Boufana B., Varcasia A. Epidemiological updates and economic losses due to Taenia hydatigena in sheep from Sardinia, Italy. Parasitol Res 2015, 114, 3137-3143.

19. Scott P.R.: Diagnosis and treatment of coenurosis in sheep. Vet Parasitol 2012, 189, 75-78.

20. Sharma D.K., Chauhan P.P.S.: Coenurosis status in Afro-Asian region: A review. Small Rumin Res 2006, 64, 197-202.

21. Soulsby E.J.L.: Helminths, arthropods, and protozoa of domesticated animals. Bailliere Tindall, London, 1986.

22. Tavassoli M., Malekifard F., Tajik H.: Prevalence of Coenurus cerebralis in sheep in Northwest of Iran. Vet Res Forum 2011, 2, 274-276.

23. Uslu U., Guclu F.: Prevalence of Coenurus cerebralis in sheep in Turkey. Vet Med 2007, 63, 678-680.

24. Varcasia, A., Lightowlers M.W., Cattoli G., Cancedda G.M., Canu S., Garippa, G., Scala A.: Cystic echinococcosis in Sardinia: farmers' knowledge and dog infection in sheep farms. Vet Parasitol 2011, 18, 335-340.

25. Varcasia A., Jia W.Z., Yan H.B., Manunta M.L., Pipia A.P., Garippa G., Scala A., Schuster R.K.: Molecular characterization of subcutaneous and muscular coenurosis of goats in United Arab Emirates. Vet Parasitol 2012, 190, 604-607.

26. Varcasia A., Pipia A.P., Dessi G., Zidda A., Tamponi C., Pau M., Scala A., Boufana B.: Morphology and genetic variability within Taenia multiceps in ruminants from Italy. Vet Parasitol 2016, 223, 181-185.

27. Williams G.T., Williams W.J.: Granulomatous inflammation - a review. J Clin Pathol. 1983, 36, 723-733. 